\title{
India-Africa: Rediscovering Trade Relations through Cultural Assimilation
}

\author{
Manish Karmwar \\ Shyam Lal College (Evening), University of Delhi, Delhi \\ Email id: mkarmwar@shyamlale.du.ac.in
}

\begin{abstract}
Indo-African trade relations are one of the imperative segments to understand African settlements in different parts of Indian sub-continent. Several Africans rose to positions of authority as generals and governors, in the Janjira and Sachin kingdoms they rose from king-makers to Emperors. The evidence of African trade in India has a significant history. From ancient times, three valuable export commodities which were prized in Africa: pepper, silk and cotton. The migration from the African subcontinent into India went up only in the sixth century A.D. but we have had an incredible trade-relation from time immemorial. From the Sixth century through the fifteenth century the history of the East African coast is somewhat illuminated by Arabs, Persians and Europeans. During the course of the sixteenth century the Portuguese dominated the Indian Ocean and its shoreline. Portugal was determined to remove Muslim merchants, especially Arabs, in the Indian Ocean system. This paper tries to explore India Africa relation especially with east Africa from earliest times to nineteenth century A.D. The paper recognizes the fact that trade and natural resources have been the principal reason behind the age-old links between Africa and India. The paper identifies the Cultural assimilation and African diaspora through the ages which has a vital facet to further strengthen the Trade Relations.
\end{abstract}

Key words: African, Assimilation, Diaspora, India \& Trade-Relations.

\section{INTRODUCTION}

India and Africa have been archaeologically, historically, politically and culturally connected during different ages through the past. The background of India's activities with Africa in the antique framework were engrossed on the continent's eastern coast, predominantly about the Horn of Africa. Different governments of India promoted stronger relationship with Africa as a continent and also country specific. In the last five years, there have been more than 28 visits at the levels of the President, Vice-President, Prime Minister and Ministers. In Gambia, on31 July 2019, India's President Ram Nath Kovind concluded his speech as the famous Wolof (NigerCongo language) phrase says, "Nyaar A Man Kenn, Ku Nu Sot Nga Jaam Ko", which means the union of two produces a great force. "Let us together be that force of change for our common 
and bright future". He also emphasised on development cooperation, based on African priorities and sustainable partnerships, is a key feature of our engagement with the continent. After South Asia, the African continent is the largest recipient of Indian overseas assistance. 181 Lines of Credit have been extended to 41 countries for a total amount of US\$ 11 billion. Africa and India together represent one-third of humanity and represent the bulk of global youth(mea.gov.in, July $312019)$.

Indian cabinet meeting chaired by the Prime Minister Narendra Modi on 21 March 2018 approved the opening of 18 new Indian Missions in Africa over a four-year period from 20182021. This would increase the number of Resident Indian Missions in Africa from 29 to 47. The decision will enhance India's diplomatic outreach in the African continent and allow India to engage with Indian diaspora in African countries. Opening of new Missions is also a step towards implementing India's vision of enhanced co-operation and engagement with Africa.

\section{HISTORIC CONTEXTUAL}

Mahatma Gandhi's time in South Africa, from 1893-1914, served as both an inspiration to nascent African national movements as well as a legitimising factor for Indian support for the anti-colonial African national movements. Gandhi's historical memory, however, has been questioned in Africa, amid revelations of his racist writings on Black Africans. Indian diaspora in the African continent, while predating British rule, greatly increased as a result of forced indentured servitude, especially in South Africa. These were the two vectors on which Indian policy toward Africa was initially based. The Bandung Conference in 1955, in Bandung, Indonesia, acted as the first Afro-Asian meeting of nations. Both the People's Republic of China and India attended, with Indian Prime Minister Jawaharlal Nehru a key organiser. The Conference gave rise to the Non-Aligned Movement (NAM), and laid the foundations for subsequent South-South cooperation. This launched India's initial engagements with Africa. Then Indian PM Indira Gandhi declared the people of Indian origin settled in Africa as "ambassadors of India"(Ghose2009,422). Foreign and domestic policy successes in the 1970s enabled Gandhi to rebuild India's image in the eyes of African states. India's Africa policy was solidified continuously throughout the years, however, under the current government of Narendra Modi. As India seeks to raise its global profile, Africa is both a conduit and an outlet for its aims. With the 2019 re-election of Modi, his government has actively sought to promote 
India as a leading power, as opposed to being simply "influential.” Much of India's narrative, as it relates to engagement with Africa, has focused on "capacity building." This strategy was elucidated by Modi's July 2018 address to the Ugandan Parliament. In this address, Modi outlined 10 guiding principles of Indian engagement in Africa. All of this, according to Modi, was to be done with "African priorities" in mind. Modi also stated that India was looking to "liberate" Africa's potential, by creating local opportunities to enable such an end (Kurzydlowski, 2020). Every claim and indication show that India's relation with Africa is working towards right direction. On 03 September 2019 remarks made by Secretary (Ministry of external affairs) at Indian Council of World Affairs Conference on "India-Africa Partnership in a Changing Global Order: Priorities, Prospects and Challenges" was a case in point. It enables an understanding of the importance of Africa as a continent and country specific. He underlined that India has been acutely responsive to the changing priorities and requirements of African countries. India has always believed in "VasudhaivaKutumbakam", i.e., the world is one family.

This paper also claims the same that a strong India Africa relationship is need of the hour but whether these developments conjunct with "African priorities." Before arriving at any assumptions, this paper is studying the trade relations between India and Africa through the ages and provides some explanations and policy implications to further reinforce India-Africa association. The paper identifies the cultural assimilation and African diaspora through the ages as being vital in further strengthening the trade relations between India and Africa.

\section{RECENT TRADE PATTERNS (2001-2017-2021)}

Bilateral trade has risen over 10-fold from US\$7.2 billion in 2001 to about US\$78 billion in 2014 , before moderating to about US\$59.9 billion in 2017, reflecting the commodity and oil price decline at the end of the commodity super-cycle, which was characterised by a synchronous slowdown in economic activity across a number of emerging and developing market economies and by heightened financial market volatility. At this pace, bilateral trade between India and Africa could reach US $\$ 117$ billion by 2021, driven primarily by improved economic ties and growing business opportunities. Though India is far behind in the actual trade value when compared to China, it has quickly sprinted ahead of other big players from advanced economies like United States, Germany, France, etc. to become one of the top actors in trade with Africa (Oramah \& Rasquinha, 2018, 53). 
According to statistics from the General Administration of Customs of China, in 2018, China's total import and export volume with Africa was US\$204.19 billion, a year-on-year increase of $19.7 \%$, exceeding the overall growth rate of foreign trade in the same period by 7.1 percentage points. Among these, China's exports to Africa were US\$104.91 billion, up 10.8\% and China's imports from Africa were US\$99.28 billion, up 30.8\%; the surplus was US\$5.63 billion, down $70.0 \%$ year on year. In 2018, the growth rate of China's trade with Africa was the highest in the world. The import growth rate was also the highest in the world, 15 percentage points higher than our import growth rate of foreign trade in the same period.

The above facts indicate that China is far ahead than India in context of value and volume of trade with Africa. Competing with China was neither earlier nor today the objective of India. China's policy was never people centric and India differ hugely on this issue. The relation of India and Africa will set an example in Asia by providing human touch in the trade relation which two countries are adopting since long time.

\section{OLD TRADE RELATIONS}

Relationship between India with East Africa through the ages and the descendants of early traders who had settled and intermarried with other races over the years form an important cluster of the ethnic grouping at various places. However, all the settlers did not come to India on their own. Many were brought as slaves for several centuries and their history is indeed a tale of sufferings on one side, the colourful episode of their rise and fall on the other. Nevertheless, some of them played unexpected, crucial and unique roles in shaping the history of the regions (Karmwar 2012,41).

From ancient times, providence had been 'kind to India' which enjoyed a superabundance of three valuable export commodities which were prized in Africa: pepper, silk and cotton. Of all the spices pepper, he thought, was rightly considered the 'greatest friend to the health of man'; 'nowhere known but in India', it grew 'spontaneously, and was gathered without toil' (Thunberg 1790, 372-373). The Periplus has little to say about the exports of Adulis and sums them up briefly as 'ivory, tortoiseshell and rhinoceros' horn. Pliny, on the other hand, relates that the port traded in a large quantity of ivory, rhinoceros-horns, hippopotamus-hides, apes and slaves. All these ports along the coast of the Horn of Africa were of international fame and were visited by vessels which either sailed there expressly or else exchanged their cargoes there while 
journeying along the neighbouring coast. Trading ships came both from Egypt whence they set forth every year in July, and from the ports between Ariaca and Barygaza on the north-west coast of the Indian sub-continent. These vessels brought the products of their own lands, such as wheat, rice, clarified butter, seasame oil, cotton cloth, girdles, and sugar, which the Periplus terms 'honey from the reed called sacchari'. The exports of these lands to the south of present-day Ethiopia included a little palm-oil and a great quantity of ivory, though inferior to that of Adulis, rhinoceros' horn and tortoise-shell, which, the Periplus says, was second only to that of India (Pankhurst 1961,22).

India first had trade with Arabs, then Portuguese through whom Africans came in contact. The forced migration of Africans from the African Continent into India went up only in the 6th century A.D. when the Arabs expanded their trade with India. After the emergence of Islam on the world scene and conquest of Persia by the Arabs in the 7th century, the Arab merchants tried to control the oceanic trade of the Konkan ports. The Arabs had not only monopolised the early carrying trade between Arabia and Malabar, but had also made several settlements on the Malabar and Konkan coasts. Much before the arrival of the Portuguese in India, a significant number of African slaves had already occupied the seats of power, not only in armies and naval forces of various rulers, but also in civil administration. The Abyssinian immigrants here gained opportunities, unequalled elsewhere, for displaying their rare capacity for sea-faring, landwarfare, management of men and civil administration. They were no longer household slaves and palace eunuchs as was the case in North or in the territories controlled by the Portuguese, but Regents of kingdoms, Generals of armies, Admirals of fleets, and Viceroys of provinces.

From the late seventh century through the fifteenth century the history of the East African coast is somewhat illuminated by Europeans and by numerous archaeological and other records. Gervase Mathew has suggested that eighth and twelfth century, under Cholas of South India must have developed flourishing trade with East Africa. With the advent of thirteenth century when Muslim influence was experienced by not only East Africa but by west Asia, this branch of trade came up with new vigour. Bulk of the Indian Ocean trading system passed into Muslim hands and all its participants acquired a new solidarity. Survivors of emporia (Adulis, Ocelis) adopted Islam and before A.D. 1000 new settlements were founded that were either Muslim from the beginning or subsequently became so. The khustestie speaking Somali, known to Arabs as 
Black Berbers, inhabiting the Benadir coast remained in close contact with Arabia and Persian Gulf and probably adopted Islam from their earliest time. The Muslim invasion and expansion in India were already brisk in thirteenth century which attracted Muslim traders from Yamen and Persian Gulf linking India directly with East Africa. Besides, there were direct trade contacts between India and East Africa in this period. Indian merchants took up residence and exercised a profound influence. Conversely, merchants from the East African coast are known to have frequented western coast of India and East at the beginning of the sixteenth century (Ali 1960,4).

There are evidences of African's role in socio-political and military life during the period of Delhi sultanate, Nizamshahi, Adilshahi, Qutbshahi, Imadshahi, Mughal India and Hyderabad till India's independence. African dispersal in India covers several states/provinces namely, Bengal, Gujarat, Maharashtra, Karnataka, Daman and Diu, Goa and Andhra Pradesh.In Gujarat, with approximately twelve thousand population they are found in the districts of Surat, Ahmedabad (Taluka Ahmedabad city), Amreli (Rajula, Kondinar,), Jamnagar (Jamnagar, Kalyanpur), Junagadh (Junagarh, Talala, Veraval, Una), Rajkot (Rajkot, Gondal), and Bhavnagar, Bharuch (Ratanpur) and the former kingdom of Kutch. Junagarh is most populated district amongst all. These villages connected to Siddis in this district are Talala, Jambur, Madhpur, MorukaBarvav, Vadva, Veraval, Mangrol, Una, Khilavad, Bilkha. Mendarda. The Uttar Kanara District of Karnataka comprises 11 talukas and out of 11, the talukas of Ankola,Yellapur, Sirsi, Mundgod, Joida, Karwara and Haliyal consists of large number of Siddi settlements and also in Khanapur of Belgaum and Kalagatgi of Dharwad district. Their language is a mixture of Sidi-Konkani and Siddi-Marathi. They also speak Kannada. In Maharashtra they are settled in Raigad district. In Uttar Pradesh they are situated in Jaunpur.

Several Africans played an important role in different Indian dynasties. The first Habshi, of whom there is historical record, was probably Jamal al-Din Yaqut, royal courtier in the kingdom of Delhi, in the north of the sub-continent. Habshis were also reported in the interior of northern India. Some of the Africans who rose to positions of considerable importance were: Malik Kafur, Malik Ambar, Malik Sarwar, Mubarak Shah, Ibrahim Shah, Malik Andil, Malik Sandal, YaqutDabuliHabshi, Ikhlas Khan, Dilawar Khan, Khavass Khan, Ulugh Khan. Their role in the History of India is Significant. The Africans, who arrived in Hyderabad, Deccan, apart from playing their traditional role as bonded guards and servants, were recruited as the Nizam's 
private bodyguard. The SiddiRisala (African Regiment) was retained until 1948. Other Siddis were elevated to the status and became trusted advisers of the Nizams (Karmwar 2010, 72).

Africans demonstrated a dynamic role in the court- politics of several rulers. They came as migrants, traders and sometimes, as slaves and were absorbed in the military and administrative services. Their engrossment in the court-politics amplified so much sometimes that they arose as king-makers. In the Janjira and Sachin kingdoms, they rose from king-makers to emperors.

Afro-Indians were interacting and responding to the changing Indian society at every stage of Indian social formation from ancient to post-independent India. They were culturally adaptive, emotionally adjustable and socially responsive to Indians and their beliefs and behaviours. AfroIndians were assimilated by inter-marriages between the Africans and local people. They were inspired by the religious tolerance of different Indian religion that is why some of Afro-Indians became Muslims, Hindus and Christians. They not only adopted the Indian culture but also assimilated to varied socio-cultural structures of Indian religions. Indian culture has been enriched and influenced by the African culture. Their connections with the host countries are more positive than merely commercial relationships; it is evident from the folk dances of the local areas of India where they reside. African musical style and dance are mostly brought into India by the Siddis in traditional forms.

Post-independence India, Indians and Africans have stressed on closer ties between the two continents. They are reclaiming their history. Their common bonds were disrupted by colonialism and they were forced to serve the economic interests of their colonial masters. The increased presence of the big powers in the Indian Ocean, have tended to prove that in view of the central geographical position, the network of vital trade routes will play an important strategic role in the future of Indo-African relationship.

UNECA and CII 2018 report on "Deepening Africa-India trade and investment partnership" illustrates the various factors, external and internal that affect the economic relations between the African continent and India. Generally speaking, Africa-India trade and investment indubitably has more potential than what is currently realised. A concentrated response from governments and regulators is needed to overcome the hurdles identified. There is a knowledge asymmetry created because of the lack of proper dissemination of information, which creates unnecessary obstacles to trade and investment between India and Africa. This stems from an incomplete 
understanding that the two sides have about each other's markets. Another advantageous enabler outside the purview of this report is the role of the Indian diaspora. They are a strong part of the African demographic and can be a powerful means of linking the two sides. African Indians are capable of serving as a bridge between the two, overcoming barriers created by language and a lack of understanding of the local systems.

The contemporary policy of Government of India towards Africa is going in the right direction. Since there exists a scope of improvement in the trade relation of two economies, a cultural bonding is also needed to enhance trade relations so that we can compete with those countries who are emerging as major trade partners in the current economic scenario. A bilateral exchange of culture may offer a higher degree of economic integration between the two economies. IndoAfrican trade relations are one of the imperative segments to understand African settlements in different parts of Indian sub-continent. The evidence of African trade in India has a significant long history.

\section{POLICY PROPOSALS}

In this respect my few policy proposals to enrich and strengthen the economic cooperation through culture and cultural assimilations are:

1. Both culturally rich economies can organise multiple cultural events to showcase each other that they have preserved the traditional customs, and rituals. More than 60,000 Siddis are living in diverse parts of India. They came to India in different circumstances through the ages and they have completely assimilated themselves in the diasporic region and rose to the power in recent times. This will give the feeling of safety and security in the foreign land, if we showcase these villages to the African world as an ideal settlement in India.

2. Both countries should focus on opening more educational institutes oriented towards their respective educational curriculum so that young minds can know and understand each other's political, economic and social system. Intermingling comfortably will no doubt bring positive impact on trade and tourism. The institutes should have a separate centre of language and literature/ linguistic department. At least all central universities should definitely have a centre on African Studies in both the countries. Introducing a separate paper in undergraduate and 
postgraduate level will broaden the horizon of understanding, which will help free mobility of human resources, a vital factor of production to strengthen the trade relation.

3. Two close knitted economies can further think on investment promotion, tariff concessions, visa free mobility, trade fairs especially in the diasporic region such as Sachin and Janjira in India to strengthen the relations. It will bring sea level change in their trade prospects.

4. Project Mausam has been initiated by Government of India. More such kind of projects are looked forward to bring out socio-cultural interaction and improve trade patterns.

5. We can redesign the ancient and medieval trading ports like Barbaricum, Barygaza Suppara, Muziris Cambay, Surat and create a cultural heritage between the two economies. This would further inculcate the cultural tie-ups, understanding and faith. The social interaction amongst India and African countries implies that the trade is bound to increase further.

6. There were/are three waves of migration: labour, traders and technicians like doctors and academicians. They interacted with each other keeping their own tradition intact. Thus, it has a meaning in formulation of foreign policy. All the waves of migration have some roles to play and their characteristics of assimilation and integration with the local people. Thus, these views highlight our long history of diasporic relation and explores the ways through which it can be made stronger to benefit each other's economies.

7. Approximately 25,000 African students are currently studying in 500 public and private universities across India, and these numbers should grow in future with increased cooperation between India and Africa, the Confederation of Indian Industry (CII) has said. The government of India will offer 15,000 scholarships to African students over the next five years to pursue online courses from the country's universities as part of a pan-African e-network project on education and medicine.

The attack on Africans in Delhi, Bengaluru and other parts of India must be stopped. It's an unfortunate fact that a large section of the Indian public view Africans with suspicious eyes. True, it can be argued that this racism charge doesn't apply to all Indians. But it cannot be denied that for a sizeable number of Indians, Africans with their dark skin, African features and seemingly alien habits are targets for contempt. 
There need to be far greater people-to-people outreach programmes. In India, people need to be exposed to Africa culture, food, history and designs. True, African embassies here do organise some events from time to time. But they are nearly not enough. The embassies, along with India's ministry of external affairs, need to work harder to get Indian and African youths talking. Africa for Indians is still a psychologically and culturally unexplored land. This needs to change if India-Africa ties are to be elevated to the next level.

To conclude, I strongly advocate that diaspora can open plethora of opportunities in bilateral trade relation through cultural interaction and assimilation. Indians have accepted a local citizenship in Africa. They have been staying in Africa for a long time in different countries like Kenya and Tanzania. Gandhiji was involved in political struggle of South Africa. Therefore, Mahatma Gandhi and his granddaughter claim to be South African first and then Indians. Many of the construction and infrastructure companies in East Africa are owned by Indians. There are Indians who consider themselves a Kenyan and Tanzanian first then Indians. No doubt the long diasporic linkages of two economies are going to boost the economic interest in the coming years.

\section{REFRENCES:}

1. Afreximbank and Exim India (2018) Deepening South-South Collaboration: An Analysis of Africa and India's Trade and Investment. Cairo: Egypt.2018.

2. Ali, S. S. 1996. The African Dispersal in the Deccan: From Medieval to Modern Times. Delhi:Orient Blackswan.

3. Basu, H., Catlin-Jairazbhoy, A., \& Alpers, E. 2004. Sidis and Scholars: Essays on African Indians. Nodia: Rainbow Publishers.

4. Bruce, J., Thunberg, C. P. \& Hearne, S. 790. Travels to discover the source of the Nile, In the Years 1768, 1769, 1770, 1771, 1772, and 1773. Vol. II. Edinburgh: Printed by J. Ruthven, For G. G. J. And J. Robinson, Paternoster-Row, London.

5. Census of India Vol.5, part 4B, No.1, 1961.Siddi-A Negroid tribe of India. Ethnographic series, Gujarat.p7.

6. Census of Siddis in Uttara Kannada.SiddiJanagadaSamagraAbivraddi Sangha, Kuchagaon, Yellapur. 2001.

7. Chandramouli, C., \& General, R. 2011. Census of India 2011. Provisional Population Totals. New Delhi: Government of India (A - 11: State Primary Census Abstract for Individual Scheduled Tribe 2011, Gujarat, Siddis.p.13.

8. Chauhan, R.R.S. 1995. Africans in India: From Slavery to Royalty. New Delhi: Asian Publication. 
9. Cohen, R. 1999. Global Diasporas: An Introduction. London: UCL Press.

10. Ghosh, A., 2009. India's Foreign Policy. New Delhi: Pearson Education

11. Karmwar, M. 2010. African diaspora in India. Diaspora Studies, 3(1), 69-91.

12. Karmwar, M. 2012. India's relations with East Africa: a historical study. Indian Journal of African Studies, 18(1-2), 39-57.

13. Knappert, Jan. 1985. The Indian Ocean before 1500'in Indian Ocean Newsletter, International Centre for Indian Ocean Research: Bentley, Western Australia, 6(2).

14. Kurzydlowski,C.(2020) What Can India Offer Africa?Amid a growing rivalry with China, how can India set its African engagement strategy apart? The Diplomate,June 27.

15. Pankhurst, R. 1961. An introduction to the economic history of Ethiopia from early times to 1800. London: Lalibela House.

16. United Nations Economic Commission for Africa (UNECA) and Confederation of Indian Industry (CII) (2018). Deepening Africa-India trade and investment partnership. Addis Ababa: Ethiopia.

17. Weber, S. A. 1998. Out of Africa: the initial impact of millets in South Asia. Current Anthropology, 39(2), 267-274. 